\title{
A SAIA COMO ATO E DISCURSO POLÍTICO CONTRA A VIOLÊNCIA DE GÊNERO
}

\author{
Adriana Tulio Baggio \\ atbaggio@gmail.com \\ Universidade Federal do Paraná - Brasil
}

Recibido: 19-02-2016

Aceptado: 04-05-2016

\section{Resumo}

Este trabalho procura demonstrar a dimensão política assumida pelo uso da saia nos dias de hoje, considerando seu uso como roupa e como figura de conteúdo em enunciados que protestam contra a violência às mulheres. Ainda que, obviamente, a violência não ocorra somente contra mulheres vestindo saia, esta é a peça escolhida para tematizar os discursos de resistência. Um dos motivos é a associação simbólica entre a saia e o feminino, entendido como categoria semântica, e sua valoração negativa em alguns espaços contemporâneos, como o da rua e o do trabalho. Para ilustrar este processo, o trabalho apresenta diversos exemplos de episódios e enunciados que têm a saia como protagonista, analisados sob a ótica da semiótica discursiva.

Palavras-Chave: Saia, política, discurso, gênero, violência contra a mulher, semiótica discursiva.

\begin{abstract}
This work aims to show that dressing skirts in these days has a political dimension. It considers its use as garment and as figure of contents in protest enunciates that struggle for the ending of violence against women. Although the violence not only occurs, obviously, against women wearing skirt, this is the element chosen for thematizing such discourses. One reason is the symbolic association between skirt and feminine, here understood as a semantic category, and its negative value in some contemporary spaces such as streets and workplaces. To enlighten this process, the paper presents several examples of episodes and enunciates that have skirt as the protagonist, analyzed from the perspective of discursive semiotics.
\end{abstract}

Keywords: Skirt, politics, discourse, gender, violence against women, discursive semiotics. 


\section{Introdução}

Como indica o título, tratamos neste trabalho de um tipo de discurso que não é aquele proferido por pessoas que atuam na política e nem aquele que versa sobre a política. $\mathrm{Na}$ verdade, seria melhor falar de uma manifestação discursiva: a saia como um texto semiótico e seu uso como uma prática social, ambos de caráter político. Para propor esta caracterização política da saia, tomamos por base uma revisão bibliográfica de história e de sociologia da moda, que tratam dos usos da saia e de sua articulação com os papéis sociais femininos em diferentes épocas. Em seguida, apresentamos situações contemporâneas de um uso político da saia, seja em discursos ou em práticas. Estes discursos, muitos deles manifestados em enunciados postados na rede social Facebook, são analisados a partir da semiótica discursiva. Tais enunciados foram coletados a partir de nossa atuação como usuária da rede entre os anos de 2011 e 2016 - processo que é detalhado no decorrer do trabalho. Enquanto os enunciados datados até 2014 integraram o corpus de parte de nossa pesquisa de doutorado (Baggio, 2014), aqueles mais recentes foram selecionados especialmente para a discussão apresentada neste artigo.

Situando a saia como vestuário símbolo do feminino ${ }^{1}$ - premissa que desenvolvemos adiante -, tal caráter político refere-se especialmente às relações de gênero. $\mathrm{O}$ feminino é entendido aqui como um dos elementos da categoria gênero, sendo o outro elemento o masculino, termo semanticamente oposto na axiologia desta categoria. Enquanto temas, feminino e masculino podem ser reconhecidos nos diversos elementos de uma narrativa e de sua manifestação discursiva (Greimas, Courtés, 2008), mas não se referem necessariamente a uma classificação dos indivíduos. A forma como se relacionam e como são valorados - positiva ou negativamente - no contexto em que são observados, revela a organização das relações de gênero em uma determinada cultura ou sociedade.

Percebe-se a construção do tema a partir dos investimentos temáticos parciais nos diversos componentes do texto semiótico, dentre os quais podemos destacar as figuras - elementos reconhecíveis no mundo natural. A saia pode ser entendida como uma das inúmeras figuras que compõem o tema e o papel temático feminino. Nas placas de sinalização de banheiros, por exemplo, são usados desenhos bastante simplificados de pessoas, que se diferenciam pela presença ou ausência de um triângulo na metade do corpo. Este triângulo é interpretado como uma saia (ou vestido, em alguns casos) e, consequentemente, a placa cujo desenho apresenta esta figura indica o (banheiro) feminino, diferenciando-o do masculino.

\footnotetext{
${ }^{1} \mathrm{O}$ vestido não tem o mesmo poder de associação que a saia. Para Anne Hollander (2003) o tipo de roupa inteiriça que depois deu origem ao vestido foi, durante muito tempo, compartilhada entre homens e mulheres. A saia surge como roupa exclusivamente feminina. A autora diferencia também a saia do kilt usado por homens escoceses. Ver outras diferenças entre saia e vestido em Baggio (2014).
} 
Não que a saia seja intrinsecamente "feminina". No entanto, por figurativizar o feminino em incontáveis textos e discursos de diferentes épocas - mesmo quando não está sendo vestida por uma mulher - é que se justifica considerá-la como símbolo ${ }^{2}$ do feminino. A semiótica discursiva entende símbolo como um elemento com estatuto autônomo, “[...] que não admite, num contexto sociocultural dado, senão uma única interpretação [...]" (Greimas, Courtés, 2008: 464). Usar ou vestir a saia, portanto, é assumir o feminino, que vai ser valorado positiva ou negativamente em sua relação com o masculino, a depender do contexto em que se inscreve este uso. Consequentemente, é também um ato político, não isento de polêmica.

Quem se dedicou a desnaturalizar e problematizar o uso da saia foi a historiadora francesa Christine Bard (2010). Logo no início de Ce que soulève la jupe, Bard pontua que as roupas têm seu gênero e que, portanto, são políticas. Nesse sentido, "Ils facilitent notre identification comme homme ou femme, avec toutes les conséquences que l'on imagine dans une société réglée par la domination masculine" (2010: 7). O paradoxal em relação à saia é que, de traje obrigatório (junto ao vestido) para as mulheres - no Ocidente, a calça foi permitida legalmente e aceita socialmente há relativamente pouco tempo -, passou a ser um direito a se reivindicar. Como mostra Bard em diversos exemplos, vestir saia tornou-se uma decisão condicionada por fatores que incluem o risco de assédio e violência. Por outro lado, e como consequência destas constrições, seu uso também manifesta um posicionamento político relacionado aos direitos civis das mulheres e ao protesto contra a violência de gênero.

O conceito de política que adotamos neste trabalho baseia-se na proposta elaborada por Eric Landowski a partir do estudo do funcionamento de diversos tipos de discursos políticos (de conteúdo político/eleitoral ou proferidos por políticos), jurídicos, ideológicos e de comunicação política que o autor apresenta nos ensaios de $A$ sociedade refletida (1992). Assim, considera-se como

“[...] proporcionador de uma dimensão política todo 'fazer' discursivo cuja efetuação vise, ou simplesmente acarrete, algum efeito de poder, entendendo, com isso, a transformação das competências modais das partes integrantes da comunicação e, por conseguinte, a transformação das condições de realização de seus respectivos programas de ação" (Landowski, 1992: $206^{3}$ ).

Apresentamos em seguida algumas reflexões sobre a história da moda em que é possível perceber a relação entre a saia e certas mudanças no papel social da mulher. Logo adiante, trazemos exemplos de situações em que a saia figurativiza a sexualidade feminina, justificando a violência de gênero e, em contraponto, situações em que a saia é reapropriada e valorada positivamente em discursos contra a violência e a favor da igualdade e da liberdade de gênero.

\footnotetext{
2 Para uma outra reflexão semiótico-discursiva sobre o simbolismo na moda, ver o trabalho de Ana Claudia de Oliveira, Nas interações corpo e moda, os discursos da aparência (2008).

${ }^{3}$ Grifo da autora.
} 
Por fim, relacionamos estes percursos narrativos com aquele que Landowski caracteriza como o "proporcionador de uma dimensão política".

\section{Rompendo barreiras de classe e de gênero}

Considerando o sujeito vestido com a saia como um texto semiótico, que manifesta certo discurso e que se coloca em interação com outros sujeitos, podemos verificar uma transformação das competências modais ${ }^{4}$ operada por certas mulheres em fins do século XIX e início do XX, quando há uma flexibilização nos modos de construção da aparência feminina, relacionada às mudanças sociais da época (Baggio, 2014).

O traje característico do Romantismo e depois da era Vitoriana apresentava diversos elementos que figurativizavam o controle social exercido sobre as mulheres burguesas. Um aspecto deste controle era seu confinamento ao espaço privado da casa e ao ócio, em oposição à atuação masculina no espaço público e no trabalho. As roupas, os acessórios e o dress code para diferentes períodos do dia, ocasiões sociais e espaços implicavam a destinação de tempo e dinheiro em quantidades acessíveis apenas a mulheres de segmentos sociais mais abastados. Tal modo de se vestir, chamado de estilo dominante (Crane, 2006), era composto especialmente de vestidos, sendo a saia uma peça com pouquíssima participação e importância na toilette (Baggio, 2014).

A partir da segunda metade do século XIX, o estilo dominante passou a conviver com outro que Diane Crane (2006) chama de "alternativo", caracterizado pela incorporação de vários itens do guarda-roupa masculino, como gravatas, chapéus, paletós, coletes e camisas (mas não a calça). Parte destes itens compõe o paradigma do vestuário para o tronco, pressupondo, então, as pernas como uma unidade sintagmática separada, a ser vestida pela saia. Esta composição distingue-se do vestido do estilo dominante em dois aspectos: pela diferença na organização sintagmática e por usar tecidos e acessórios mais simples e em quantidade muito menor.

Consciente ou não, o estilo de vestuário alternativo representava uma resistência ao estilo dominante e às mulheres que podiam (ou deviam) usá-lo: mulheres de classe alta, casadas e que não trabalhavam (Crane, 2006: 48-49). Por isso, a inclusão de elementos masculinos (simbolizando a independência e não necessariamente questionando a autoridade masculina) no traje foi adotada, primeiramente, pelas jovens trabalhadoras de classe média e operária e pelas mulheres solteiras, dois grupos relativamente "marginais" considerando-se o ideal da época. Porém, diferente do que ocorria com as reformistas do vestuário, este ato de resistência não era destinado por uma consciência feminista, e sim por uma crítica às diferenças de classe social. Este estilo, no entanto, relativamente mais barato e descomplicado, acabou cruzando as

\footnotetext{
${ }^{4}$ Querer e dever, saber e poder (Greimas, Courtés, 2008: 76).
} 
fronteiras de classe (Crane, 2006: 268) e, por volta de 1920, com as criações de Coco Chanel, percebe-se sua chegada à classe alta francesa, passando a compor o estilo dominante.

Além de romper as fronteiras de classe, o estilo alternativo contribuiu para minar as barreiras de gênero. Assim como ocorreu com o corpo masculino, a separação de tronco e pernas em duas unidades sintagmáticas vestimentares significou assumir que existe o sexo no corpo feminino, constatação que ficará visualmente mais forte - e por isso a interdição persistente por tanto tempo - com a adoção da calça. A calça, no entanto, é uma peça masculina e assume o sexo de um jeito originalmente masculino. A saia é feminina, e usar saia é uma afirmação da sexualidade feminina.

\section{A saia nos discursos de protesto}

\subsection{Por que usar saia passou a ser um problema?}

$\mathrm{O}$ uso da saia pelas mulheres diminui sensivelmente em fins do século XX e início do XXI, conforme observa Christine Bard (2010). Este "abandono" em detrimento da calça seria maior entre adolescentes e jovens, devido ao risco de assédio e violência. No entanto, apesar do uso generalizado da calça, a saia não saiu de moda. Seu poder erótico de roupa aberta atrai, estimula o jogo de sedução, proporciona o prazer estésico (o prazer da percepção das sensações) do contato da pele nua com o tecido, enseja um vestir-se para si e também para o outro. Muito por conta disso começa a se estabelecer a associação saia = disponibilidade sexual.

Mulheres, especialmente as mais jovens, que usam saia e outros recursos de "feminilidade", são tachadas de "fáceis", sanção aplicada por um destinador-julgador que considera a expressão da sexualidade feminina como o descumprimento de um certo tipo de contrato. Tal constatação pode ser percebida em diversos discursos do cotidiano e também em sondagens mais criteriosas, como um estudo francês sobre os jovens e sua relação com a cidade, realizado em 2008 (Clair citada por Bard, 2010: 68). Os entrevistados apontaram certas roupas e acessórios interditos às meninas por sua associação com uma sexualidade adulta, dentre eles a saia.

Na lógica desta narrativa, o uso destas peças sinaliza uma provocação sexual e uma intenção que justifica a culpabilização da vítima em caso de agressão. Ou, como se ouve em muitas falas de agressores: "ela estava pedindo". A saia é usada somente em condições muito específicas, quando a moça sai com o namorado, por exemplo. No dia-a-dia e nos espaços públicos da escola e da vizinhança, para se fazer respeitar, as meninas se vestem de forma parecida à dos meninos. Para Bard, "la jupe est mise en évidence comme un nouveau tabou, et le pantalon comme un moyen de dissimuler la féminité (parlet-on de dissimuler la masculinité?). La jupe signifierait: 'J'assume mon corps et ma féminitée' (2010: 94). 


\subsection{Pelo direito de usar saia: as manifestações francesas}

A insistência nesta expressão da feminilidade estaria na base de episódios extremamente violentos, como o caso de uma moça de 17 anos, queimada viva nas lixeiras de uma localidade no subúrbio de Paris ${ }^{5}$, em 2002, e os constantes estupros coletivos que ocorreram na época. Estes eventos levaram à realização de diversos tipos de protesto contra a violência feita às mulheres, muitos deles adotando a saia como figura emblemática, como é o caso do movimento Ni putes ni soumises ${ }^{6}$.

O Ni putes ni soumises se propõe a lutar pela liberdade de as mulheres se vestirem do jeito que desejarem, sem serem agredidas por isso. Entre as peças que mais causam polêmica no vestuário feminino está, junto à saia, o véu ${ }^{7}$ islâmico. Mas é a saia que "veste" o punho da manifestante no logotipo do movimento (figura 1A) e, para as integrantes dele, "porter une jupe est um acte militant" (Bard, 2010: 71). Em 2005 a televisão francesa dedicou um dia inteiro de sua programação ao aniversário de dois anos do movimento, e a peça publicitária de divulgação desta homenagem também trazia a saia em destaque (figura 1B).

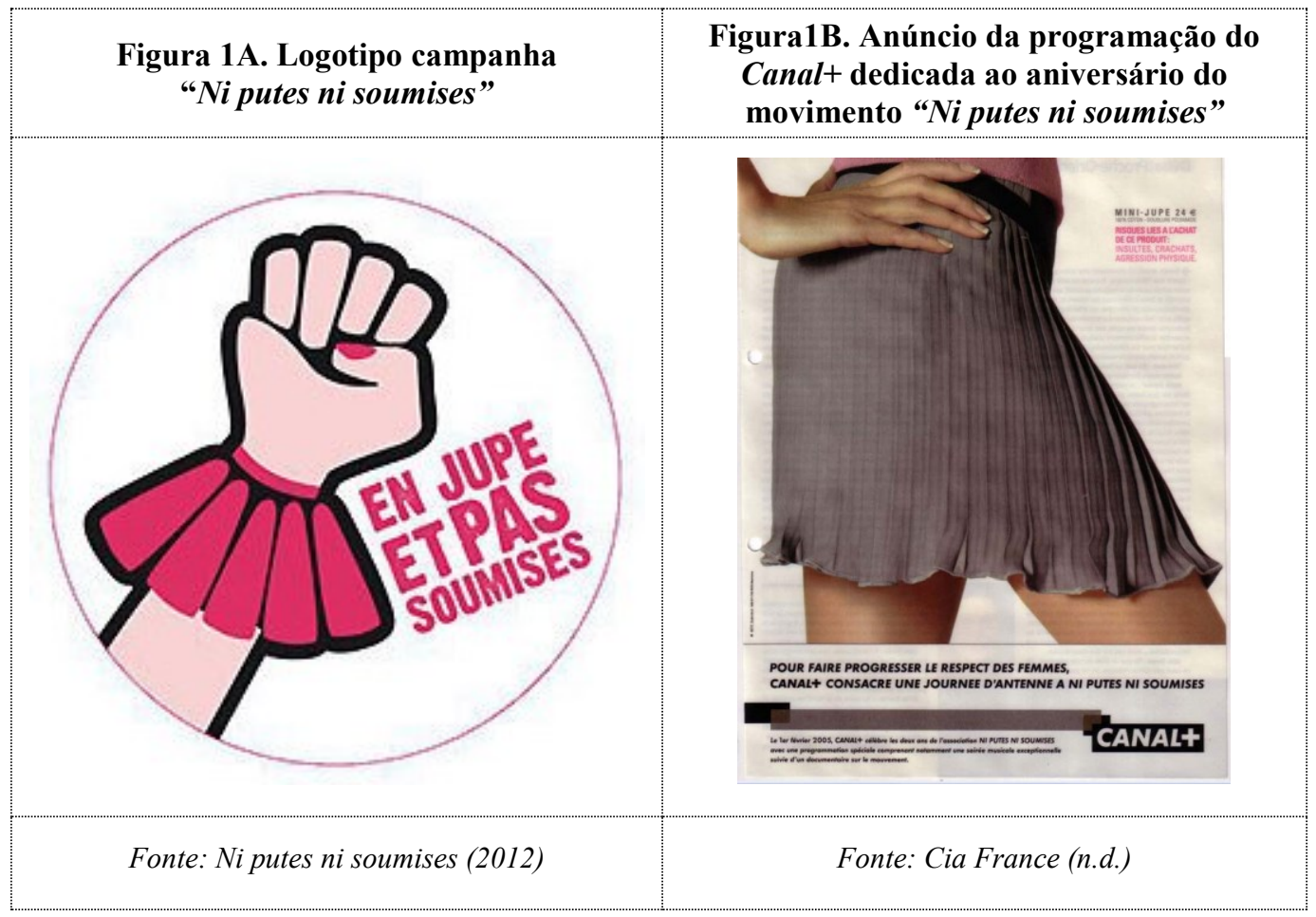

\footnotetext{
${ }^{5}$ Sohane Benziane foi morta no dia 4 de outubro de 2002, em Vitry-sur Seine, por afrontar as normas de um chefe de gangue local, de 19 anos. O site do Ministério francês que se ocupa dos direitos das mulheres publicou em 2 de outubro de 2012 um artigo para lembrar os 10 anos da morte da jovem (Ministère des Familles, 2012).

${ }^{6}$ O site do movimento: http://www.npns.fr [14/06/2011].

${ }^{7}$ Anne Hollander (2003: 65) aponta também o véu, junto à saia, como a peça-símbolo da mulher.
} 
O texto verbal no canto superior direito do anúncio remete aos enunciados publicitários: "Minissaia $24 €$. 100\% algodão, forro em poliamida. Riscos relacionados à compra deste produto: insultos, cusparadas, agressões físicas”. A advertência dos riscos faz referência ao texto obrigatório de produtos considerados perigosos à saúde, como cigarro e bebidas alcoólicas, que as pessoas consomem estando cientes destes riscos. Neste sentido, se o consumidor for prejudicado por tais produtos, é porque "procurou".

A associação desta lógica com o uso da saia alerta para a prática de culpabilização da vítima pela violência sexual sofrida. No entanto, a postura da modelo no anúncio não é de alguém acuada ou desavisada. Pelo que se pode ver do corpo e da forma como a saia se ajusta a ele, a moça está com a perna direita posicionada à frente, dobrada, provavelmente apoiada na ponta do pé ou em um suporte mais alto que o chão. Tal postura acentua a abertura e o efeito de acesso e vulnerabilidade deste tipo de roupa. Esta situação não parece intimidá-la, já que sua mão direita está na cintura, sugerindo que sua postura é intencional e até mesmo desafiadora, se considerarmos a articulação da imagem com a advertência do texto verbal. Nota-se, também, que a expressão plástica da saia traz muitas figuras integrantes do tema da feminilidade: o plissado; o ondulado da bainha, formando um babado; a leveza do tecido, que parece prestes a se levantar com qualquer deslocamento de ar mais forte; a forma levemente ampla, e não ajustada. Assim, o anúncio articula os dois sentidos assumidos pela saia em práticas e discursos contemporâneos: o da disponibilidade sexual que justifica o exercício da violência e, em protesto a isso, o da afirmação do direito ao exercício do feminino, em qualquer espaço e sob qualquer circunstância.

Os episódios que deram origem às manifestações, ou ao menos aqueles que tiveram maior visibilidade, aconteceram com mais frequência nos subúrbios parisienses habitados por imigrantes de religião islâmica. Por conta disso, o Ni pute... foi acusado de ter um viés preconceituoso e de ter sido usado politicamente pelo ex-presidente Nicolas Sarkozy na sua cruzada contra o uso público do véu (Bard, 2010: 73). No entanto, Bard vai mostrar que estas constrições estão presentes em todos os meios e em todo território francês - e não apenas nos arredores da capital -, gerando igualmente diversos tipos de manifestação contra a violência que têm em comum a saia como elemento simbólico.

Um exemplo é o "Dia da Saia e do Respeito", realizado em 2006 por alunos e professores de um colégio particular agrícola da região de Rennes, na Bretanha. A ação teve boa repercussão e deu origem ao Printemps de la jupe et $d u$ respect ${ }^{8}$, que acontece até hoje em diversas escolas e universidades de toda a França. Para a autora, a experiência bretã do "Dia da Saia" permite constatar que a situação de risco que estigmatiza a saia e leva à necessidade de usar a calça como uma veste protetora "[...] concerne, au début du XXIe siècle, toutes les jeunesses: rurale, urbaine, catholique, musulmane, blanche, noire...” (Bard, 2010: 104).

Apesar desta recorrência da saia em atos de protesto, foi sem saber do Printemps de la jupe et $d u$ respect que o diretor Jean-Paul Lilienfeld produziu La journée de la jupe (figura 2A),

${ }^{8}$ Site da ação: http://www.printempsdelajupe.com [18/02/2016]. 
estrelado por Isabelle Adjani. O filme foi ao ar na TV francesa em março de 2009, após enfrentar bastante rejeição por tratar de um tema considerado muito sensível. Parte desta "sensibilidade" deve-se, mais uma vez, ao cenário em que as situações de violência ocorrem: uma escola nos subúrbios de Paris.

Adjani interpreta Sonia Bergerac, professora de francês que se recusa a aceitar o comportamento desrespeitoso e violento dos alunos. Tal posicionamento destoa daquele assumido por seus colegas, que evitam possíveis confrontos sujeitando-se às chantagens e mau comportamento dos estudantes. Esta diferença de atitude é um dos motivos que fazem de Bergerac uma professora não muito apreciada por seus pares. No entanto, o principal foco de desaprovação é Bergerac insistir em ir trabalhar de saia.

A professora percebe que a mesma lógica de valoração negativa do feminino que vigora entre o corpo docente, perpetua-se entre os alunos. Ao confrontar um estudante armado e tomar dele o revólver, Bergerac fecha-se com a turma em uma sala. No confinamento, vêm à tona diversos episódios de intimidação, assédio e violência sexual.

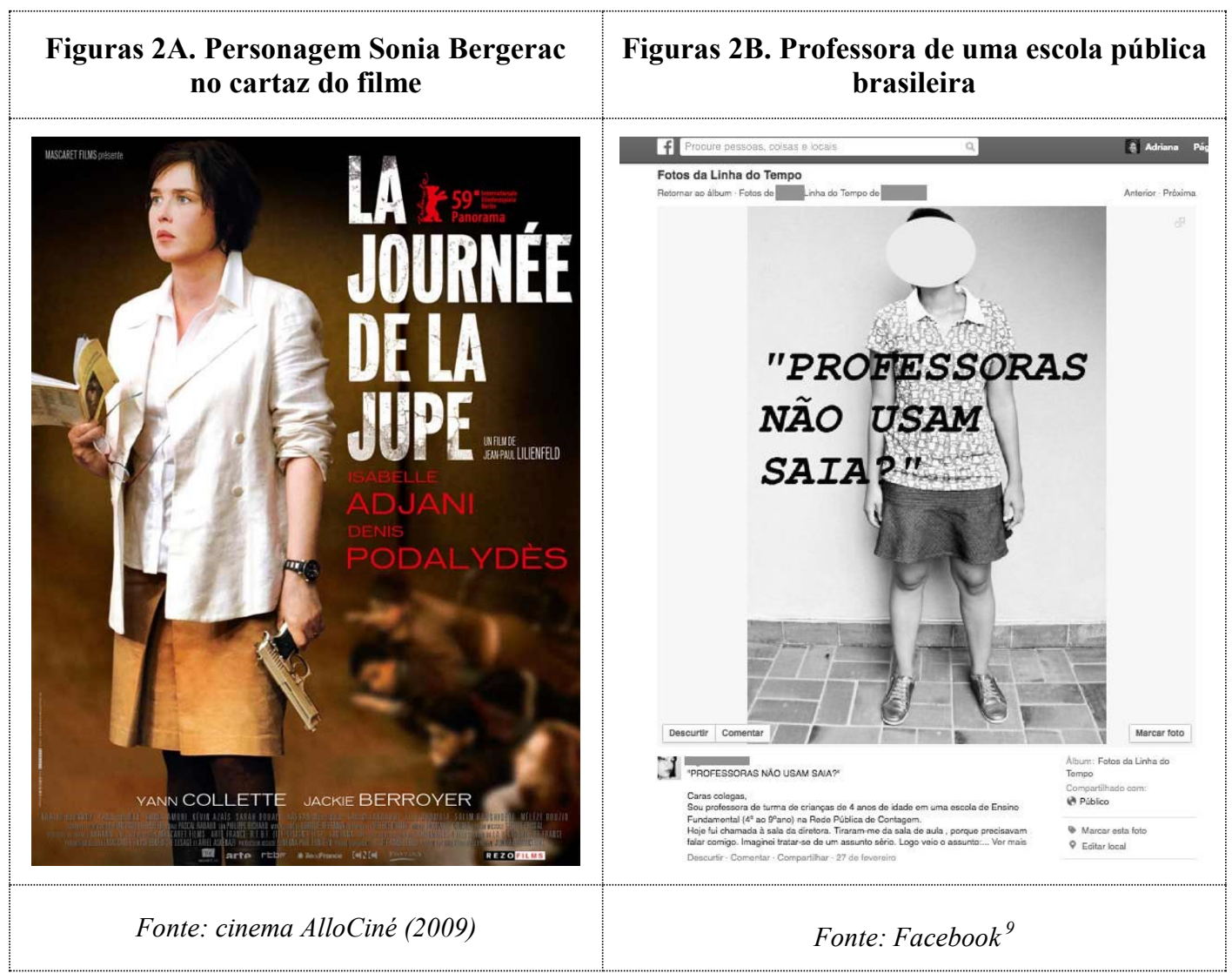

\footnotetext{
${ }^{9}$ Imagem da postagem no Facebook obtida por meio de impressão de tela do post publicado pela professora [03/03/2015]. A postagem não está mais disponível (ver nota 10).
} 
A situação torna-se caso de polícia. Pressionada a soltar os alunos, faz uma reivindicação política: que o governo institua o "dia da saia", um dia por ano em que as alunas poderão ir de saia à escola sem medo, "um dia em que o estado afirma que se pode vestir uma saia e não ser puta" [fala da personagem Sonia Bergerac, com grifo nosso]. O pedido é ridicularizado pela ministra da Educação (que veste calça). A professora acaba morrendo na operação de resgate, mas o filme termina sugerindo que a reivindicação teria surtido algum efeito: as alunas vão ao seu enterro vestindo saia, roupa que não se atreviam a usar na escola.

\subsection{Problemas com o uso da saia em outros países}

Se o exemplo bretão mostra que as constrições ao uso da saia não atingem somente as regiões em que vivem imigrantes muçulmanos, a história do filme indica que o problema não afeta apenas mulheres jovens. E como mostram os exemplos seguintes, também não se restringem aos episódios observados na França.

No Brasil, a diretora de uma escola de ensino fundamental teria advertido uma de suas professoras pelo fato de usar saia no trabalho. Segundo depoimento ${ }^{10}$ da professora (figura $2 \mathrm{~B}$ ), a diretora dizia que apesar de a saia não ser curta, as pernas chamavam a atenção dos adolescentes. Não haveria problema em usar bermuda, mas não bermuda por baixo da saia: o uso da saia em si estaria sendo questionado (Marçal, 2015).

A associação da saia com uma atitude provocativa da mulher já havia sido observada no Brasil alguns anos antes, como indica uma reportagem sobre assédio publicada em 2008 na revista TPM. Dois depoimentos mostram o medo como forte destinador da decisão de não usar esta peça de roupa. Uma estudante universitária, moradora de região nobre da megalópole São Paulo, justifica: "tento não colocar saia nem quando está calor porque sei que os caras vão olhar de um jeito que me agride ou vão falar baixarias nas ruas". Uma jovem jornalista do Rio de Janeiro dizia não usar mais saias à noite porque cansou de ser atacada (Lemos, Tambellini, 2008: 31).

Assédio de rua associado ao uso da saia também é tratado no documentário belga Femme de la rue, de 2012, em que alguns depoimentos apontam o uso da calça ao invés de saia como forma de se evitar a violência nas ruas de Bruxelas (Melro, 2012). E mesmo o poder público reproduz a lógica de culpabilização, como é o caso do policial de Nova Iorque que advertiu uma mulher por estar andando de bicicleta de saia curta, "distraindo os motoristas" (ColvilleAndersen, 2011). Este último episódio acabou gerando um protesto, o Short Skirt Celebration Ride, que a exemplo de outros apresentados adiante ressignifica a saia como emblema da manifestação contra o preconceito e a violência de gênero.

\footnotetext{
${ }^{10}$ A professora denunciou o episódio em 27 de fevereiro de 2015 , em seu perfil pessoal na rede social Facebook. O post original foi removido, mas outros veículos de comunicação divulgaram a história reproduzindo o conteúdo da postagem, a exemplo do que citamos no texto (Marçal, 2015).
} 
Outra modalidade de assédio sofrido por quem usa saia é o upskirting, ato de fotografar por baixo da roupa de mulheres em espaços públicos. A prática ganhou visibilidade, ao menos nos Estados Unidos, quando passou a ser considerada crime no estado de Massachusetts, em 2014.

O upskirting pode ser feito por baixo de outras peças, como blusas. Mas o exemplo usado por um site de fotografia que chamava a atenção para a impunidade desta prática é de uma mulher que aparentemente veste saia (figura 3). Sem falar, obviamente, na presença da palavra "saia" (skirt) no nome.

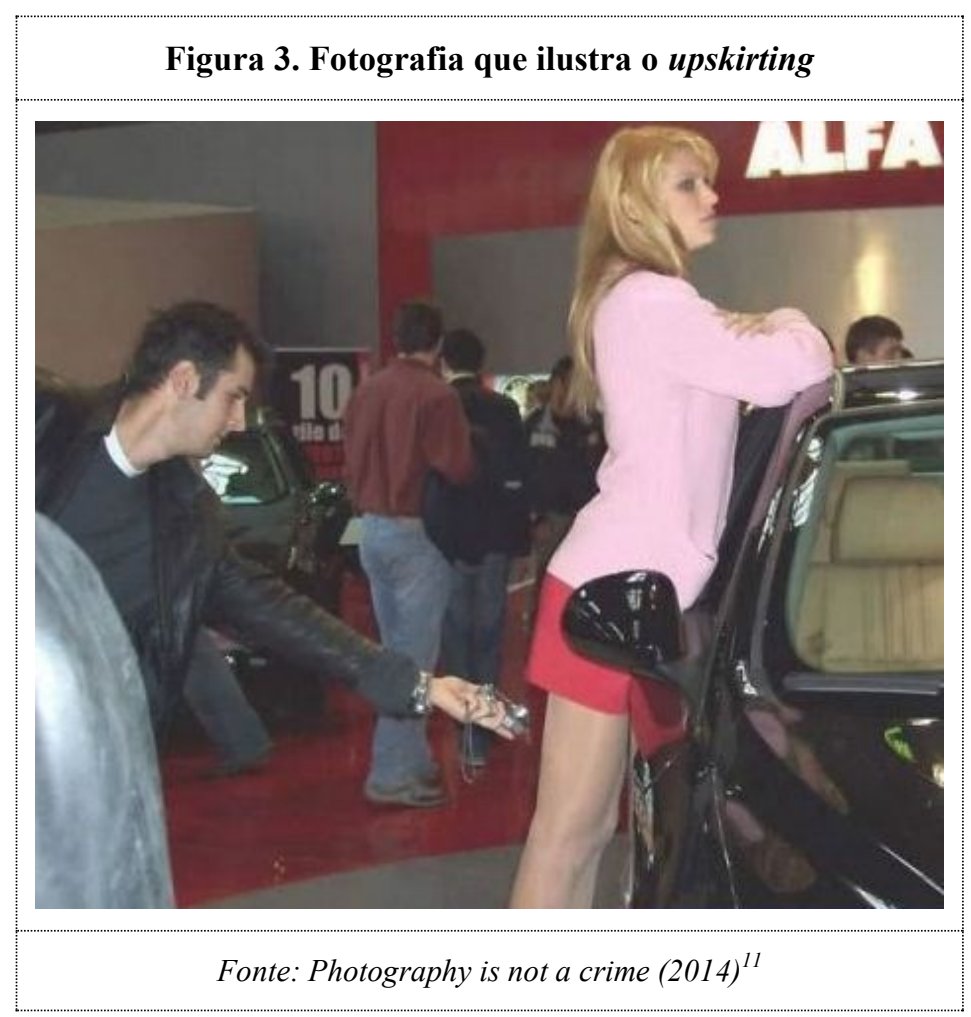

Os exemplos mostrados até agora se referem ao uso da saia no cotidiano e aos problemas que daí advém, e também ao uso em práticas sociais de protesto - sejam elas reais ou na ficção. O que apresentamos em seguida são manifestações discursivas que chamam a atenção para a violência contra mulher e que constroem sua produção de sentido a partir da saia. A saia é tomada como um elemento simbólico dos aspectos mais gerais do feminino apontados pelos agressores para justificar a violência.

\footnotetext{
${ }^{11}$ Fotografia publicada em reportagem intitulada "Massachusetts Supreme Court Rules it's Legal to Record up Women's Skirts in Public". Dois dias depois seria promulgada a lei que criminaliza o upskirting. A fotografia é de 2006 e foi retirada de um perfil público do site de compartilhamento de fotos Flickr.
} 


\section{A saia nas mensagens de protesto em sites de redes sociais}

A saia, como figura de conteúdo, está presente em enunciados verbais e visuais de mensagens de protesto veiculadas em sites de redes sociais, como o Facebook. Os exemplos aqui apresentados foram coletados por meio de nosso uso desta rede ${ }^{12}$. Não foi feita uma busca ativa por enunciados que contivessem a saia em figura verbal ou visual. Quando estes exemplares apareciam em nossa timeline, eram coletados e analisados.

A timeline, ou página de cada perfil na rede, torna-se uma espécie de mural de notícias, formado por conteúdos postados tanto pelo titular do perfil quanto por seus contatos. Para Fábio Malini e Henrique Antoun, que tratam do ciberativismo e mobilização nas redes sociais, "[...] cada perfil é uma comunidade de autores, a informação criada termina por traduzir verdadeiras 'quantidades sociais', exprimindo uma amostra das crenças e dos desejos da sociedade em torno de algum tema, alguma hashtag ou alguma postagem" (2013: 14).

É como uma amostra sobre o sentido que a saia tem assumido em nossa sociedade que entendemos a pertinência de observar sua reiteração nestes enunciados de protesto (figuras 4A, 4B, 4C, 4D, 4E e 4F).

Percebe-se uma recorrência de respostas à prática de culpabilização da vítima: a saia não é um convite (retomando aqui o aspecto sexualizador desta peça, como apontamos no item 1); a saia não caracteriza uma prostituta (ideia duplamente problemática, porque além da valoração social negativa da prostituição, entende-se também que a mulher prostitua é desprovida de direitos sobre o próprio corpo); a saia não é motivo para que uma mulher seja estuprada (sendo o estupro um tipo de castigo para a não cumplicidade da mulher com certas regras que devem ser seguidas por seu gênero). Já a figura 4c ilustra que a violência de gênero que afeta as mulheres pode partir de outras mulheres, daí o motivo de tratarmos de feminino e masculino como categorias semânticas.

Evidentemente, não são apenas mulheres usando saia que sofrem violência e que são culpabilizadas pela violência sofrida, mas a saia é a figura escolhida para representação deste processo nos enunciados analisados, por conta do seu simbolismo com o feminino.

\footnotetext{
${ }^{12}$ As imagens que trazemos aqui foram retiradas de perfis que classificaram a postagem como "pública", ou seja, disponível para ser visualizada por qualquer pessoa na internet, por isso indicamos o link da postagem original. No entanto, nem sempre temos a informação sobre a autoria das ilustrações, fotografias, cartazes e layouts. Algumas postagens também podem ter sido removidas pelos usuários.
} 

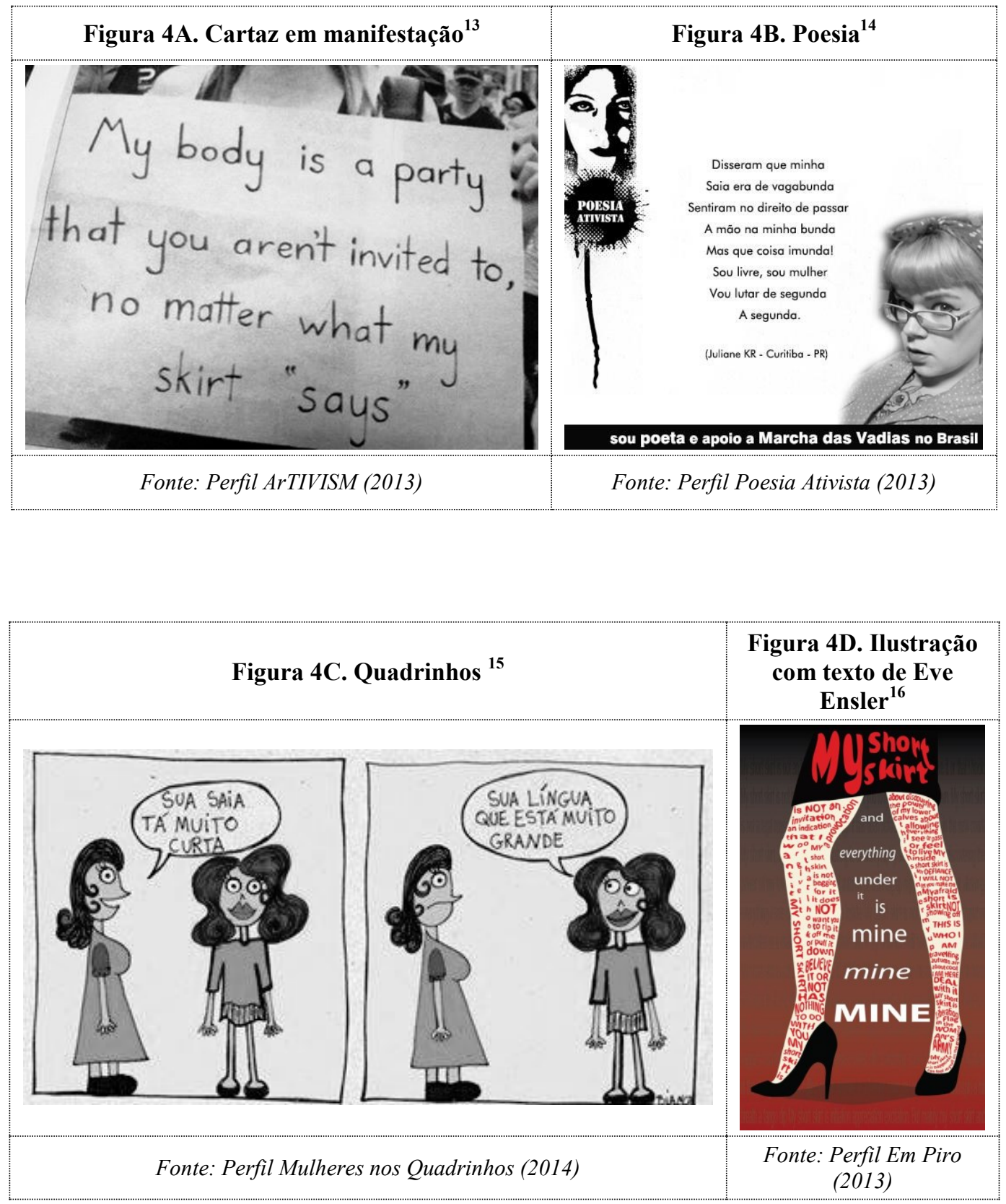

\footnotetext{
${ }^{13}$ Fotografia de cartaz em manifestação, sem autoria.

${ }_{15}^{14}$ Autoria do texto de Juliane KR.

${ }^{15}$ Autoria da cartunista mineira Bianca, que publica seus trabalhos na fan page intitulada Anna Bolena - A perturbada da corte.
} 


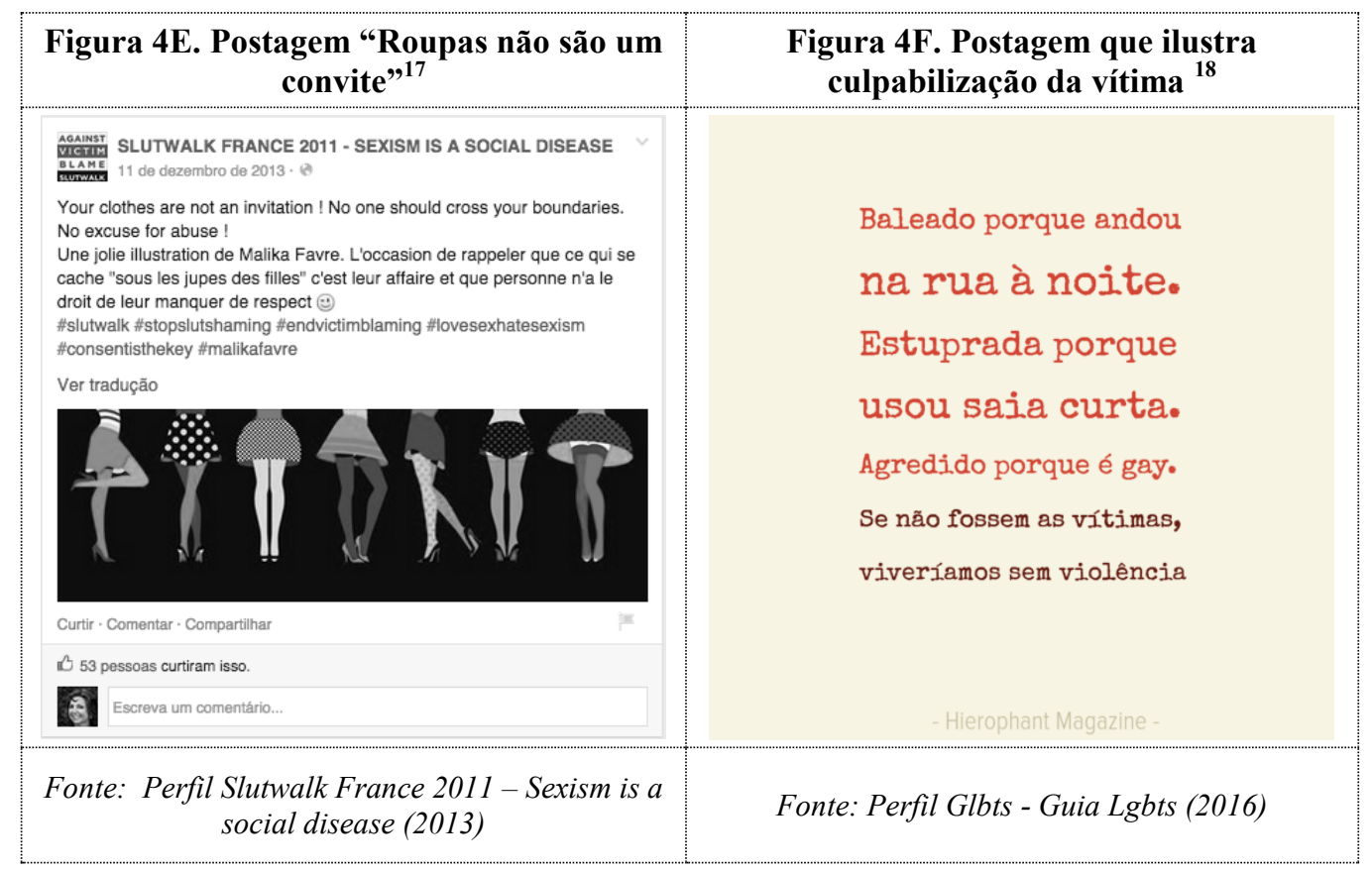

Uma das imagens mais emblemáticas deste conjunto de enunciados coletados no Facebook - e por conta disso tratamos dela separadamente - é uma intervenção artística produzida em 2013 pela estudante de artes canadense Rosea Posey. A fotografia mostra a parte de trás das pernas de uma mulher usando saia (figura 5A). Uma das pernas está demarcada com os possíveis comprimentos de saia que se pode usar e os julgamentos que serão atribuídos.

O comprimento mais longo, já perto do tornozelo, é chamado de "matronal"; em seguida vêm "pudica" e "antiquada"; na altura do joelho é "adequada"; daí para cima os comprimentos levam a pessoa que usa a saia a ser julgada como "sedutora", "atrevida", "provocante", "está pedindo", "vadia" e, no comprimento mais curto, "prostituta". Não há formas "positivas" de se usar saia, pois é o feminino em si que é estigmatizado.

Em 2014, alunos da Miami Ad School de Hamburgo criaram uma campanha ${ }^{19}$ publicitária para a organização suíça Terres de Femmes, focada em direitos humanos e na igualdade de gênero, intitulada “Don't measure a woman's worth by her clothes".

\footnotetext{
${ }^{16}$ Arte sem autoria. O texto que preenche as pernas da figura feminina é um trecho da peça Os monólogos da vagina, de Eve Ensler.

${ }_{17}$ Autoria de Malika Favre.

18 Autoria de Hierophant Magazine.

19 As peças podem ser vistas em diversos sites que tratam do mercado publicitário, a exemplo do Ads of the world, que também traz a informação de serem peças "fantasmas" (não-veiculadas, no jargão publicitário).

Disponível em: http://adsoftheworld.com/media/print/terre_des_femmes_a_womans_worth_3 [17/02/2016].
} 
Os três anúncios da campanha mostram partes de corpos femininos usando peças consideradas marcas de disponibilidade sexual - e consequente justificativa para violência -, como uma blusa decotada, um sapato de salto alto e uma saia (figura 5B). As peças nunca foram veiculadas, mas apareceram em diversos sites que tratam do mercado publicitário. Apesar da semelhança com a intervenção artística de Posey, não há menção a ela na ficha técnica da campanha.

O próximo conjunto de enunciados (figuras 6A, 6B, 6C e 6D) publicados no Facebook também têm como foco o protesto contra a violência de gênero, mas foram elaborados em resposta à uma situação específica: os resultados da pesquisa brasileira "Tolerância social à violência contra as mulheres" (Instituto, 2014).

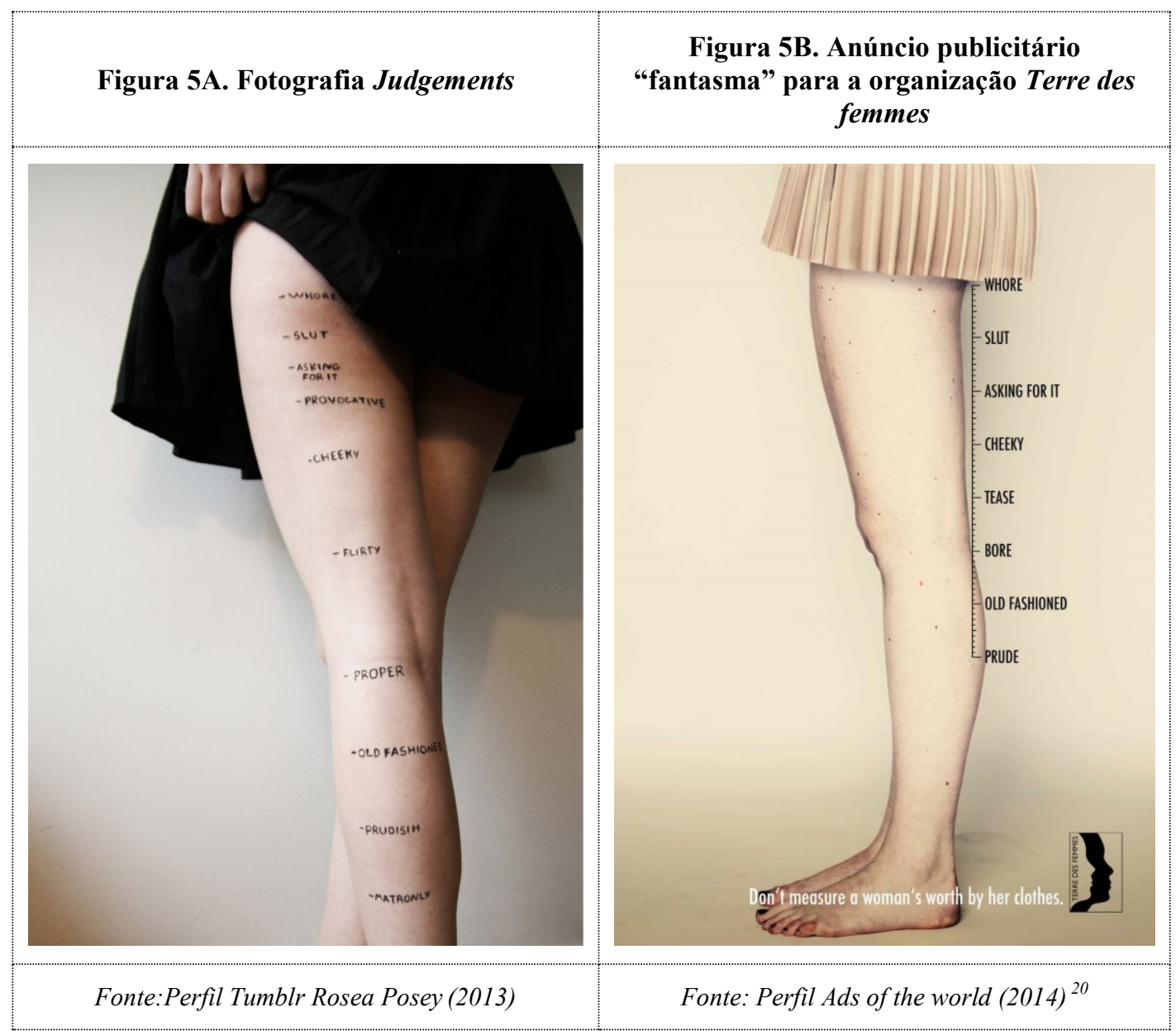
${ }^{20}$ Anúncio elaborado por alunos da Miami Ad School de Hamburgo. Ver ficha técnica na referência da
nota 19 . 


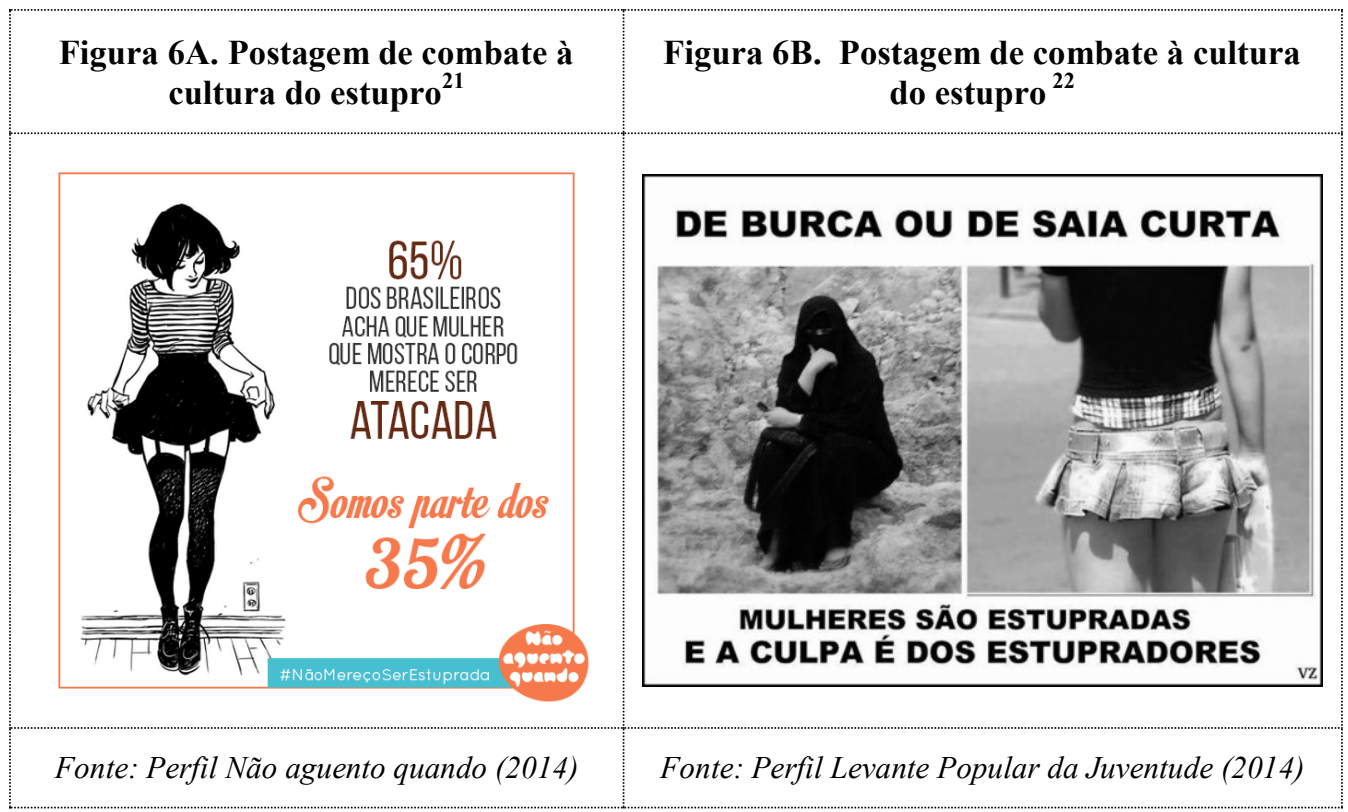

Figura 6C. Postagem de combate à cultura do estupro ${ }^{23}$

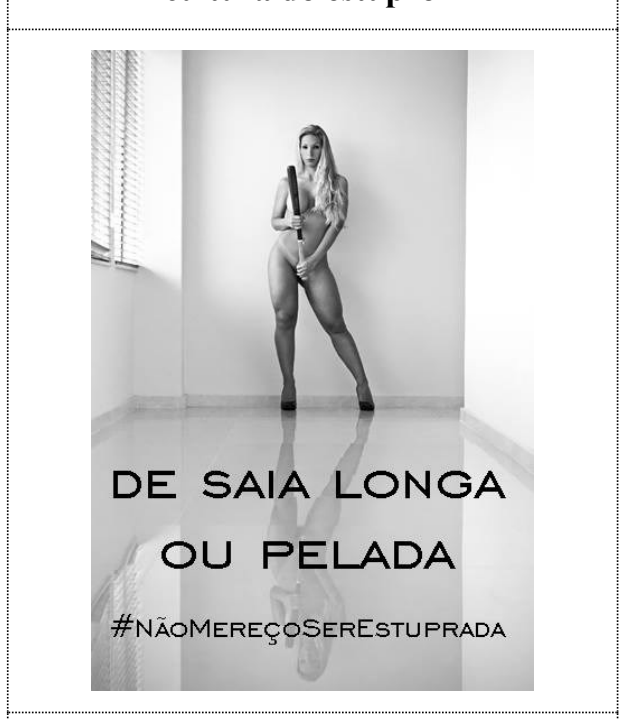

Os resultados foram divulgados no dia 28 de março de 2014. Um dos dados mais alarmantes indicava que $65 \%$ dos brasileiros concordavam, ao todo ou em parte, que uma mulher usando roupas curtas merecia ser atacada.

No dia 4 de abril divulgou-se uma errata, informando que uma troca de gráficos entre duas questões resultou em interpretação incorreta dos dados.

A parcela da população brasileira que concordava com o ataque a mulheres com pouca roupa não era de $65 \%$, e sim de $26 \%$ (um número menos assustador, mas que ainda assim não justifica o uso da expressão "só $26 \%$ ", adotada por certos veículos da imprensa).

Fonte: Perfil Valesca Popozuda (2014)

\footnotetext{
${ }^{21}$ Sem informação de autoria.

${ }^{22}$ Sem informação de autoria.

${ }^{23}$ Sem informação de autoria. No texto que acompanha a imagem, a postagem destaca outro dado da pesquisa do Ipea, que diz que $58,5 \%$ dos entrevistados concordam com a frase: "Se as mulheres soubessem como se comportar, haveria menos estupros".
} 


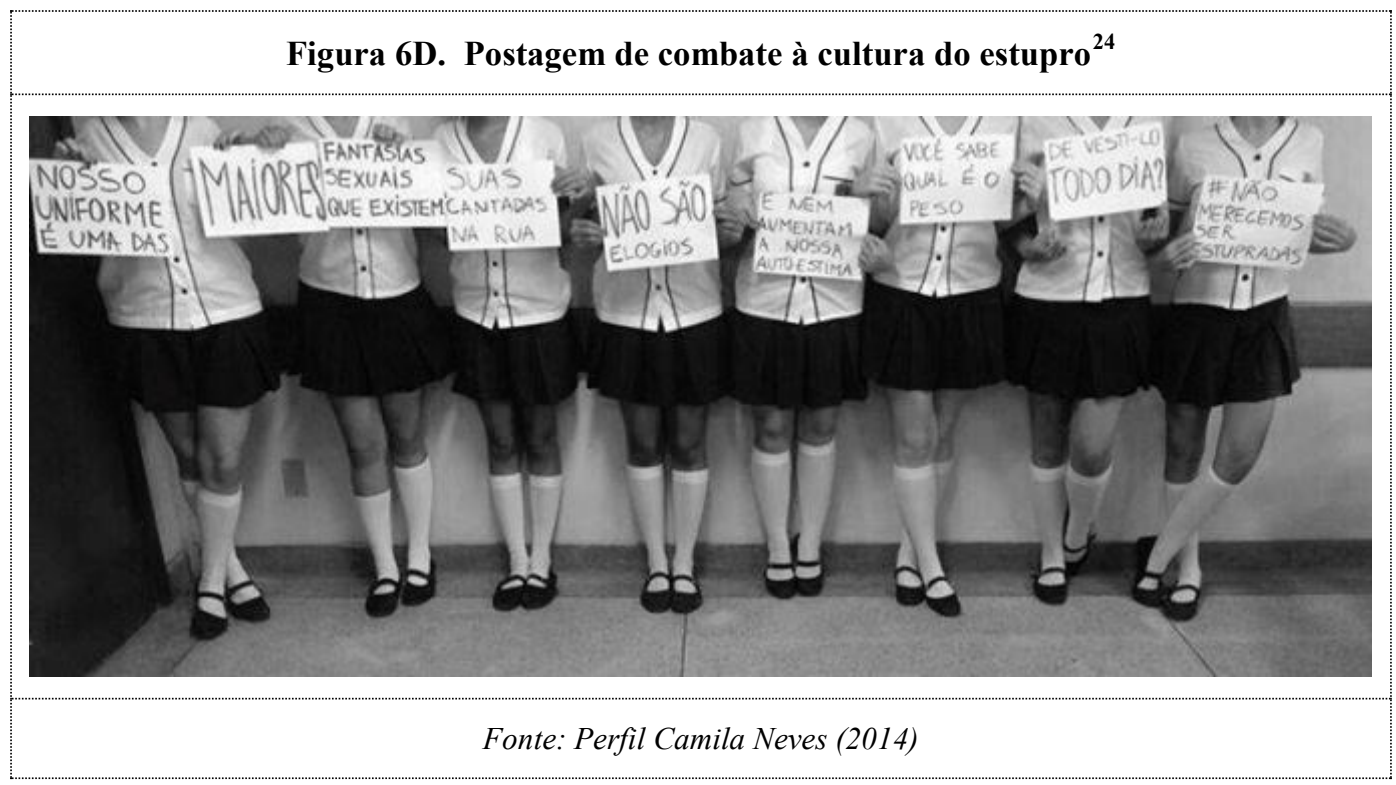

Muitas das imagens produzidas em protesto à situação indicada pelos resultados da pesquisa vinha acompanhada da hashtag \#NãoMereçoSerEstuprada. E apesar de a pesquisa não se referir à saia em nenhum momento, e sim ao procedimento mais generalizado de culpabilização da vítima, é a saia que frequentemente ilustra a roupa e o comportamento destinadores da violência.

Vimos até agora conjuntos de enunciados contra a violência, especialmente aquela dirigida às mulheres, que têm as próprias mulheres como autoras e/ou destinadoras das mensagens. No caso das manifestações estudantis apresentadas no item 3, elas envolviam alunos de ambos os sexos. Mas há uma exceção. Na primavera europeia de 2014, em Nantes, no oeste da França, meninos usaram saia para ir à escola em protesto contra o sexismo ${ }^{25}$. A iniciativa se chamou $C e$ que soulève la jupe, em alusão ao livro de Bard.

A iniciativa mostra uma percepção importante, especialmente entre os jovens: a violência contra mulher é fruto do sexismo, mas o sexismo não afeta somente as mulheres. O preconceito é responsável por outras formas mais ou menos explícitas de violência relacionada à quebra das regras que regem a aparência, a identificação e a performance de gênero, afetando qualquer pessoa, inclusive os homens. E quando indivíduos ou grupos masculinos se manifestam contra este tipo de constrição, também encontramos a saia como figura emblemática de suas práticas e discursos.

\footnotetext{
${ }^{24}$ Sem informação de autoria. O texto verbal dos cartazes forma o seguinte enunciado: "Nosso uniforme é uma das maiores fantasias sexuais que existem. Suas cantadas na rua não são elogios e nem aumentam a nossa auto-estima. Você sabe qual é o peso de vesti-lo todo dia? \#NãoMerecemosSerEstupradas".

${ }^{25}$ «Ce que soulève la jupe»: à Nantes, la polémique laisse la communauté éducative perplexe (Battaglia, Gauchard e Laurente, 2014).
} 


\section{O uso masculino da saia}

Para a historiadora Anne Hollander (2003), houve diversos empréstimos do guarda-roupa feminino ao masculino - os exemplos mais notáveis estão nos trajes do Antigo Regime -, mas a saia nunca foi um deles, justamente pela forte caracterização desta peça como "roupa de mulher". Com a flexibilização contemporânea dos modos de construção da aparência e da performance de gênero, alguns homens passaram a reivindicar o uso cotidiano da saia ${ }^{26}$. No entanto, a adoção da peça por vezes gera atos de repúdio e violência, especialmente pela associação com a homossexualidade.

Da mesma forma que a violência contra a mulher, aquela praticada contra os homossexuais também não está exclusivamente associada à saia. Mas percebe-se que, ao vestir esta peça, seja hetero ou homossexual, o homem pode ser alvo de ataques que não receberia caso cumprisse o código vestimentar socialmente atribuído ao seu gênero. E nos protestos contra a proibição ou a violência - chamados de "saiaço" -, a saia também é símbolo.

Alguns episódios de maior repercussão no Brasil aconteceram em instituições de ensino. Em maio de 2013, um aluno da Universidade de São Paulo foi ofendido pela internet por ter ido assistir aula de saia; em reação, estudantes de outros cinco campi da instituição promoveram um protesto em que os homens vestiriam saia, e as mulheres, roupas masculinas ${ }^{27}$. Em maio do mesmo ano, dois alunos do Colégio Bandeirantes, também em São Paulo, foram censurados pela direção da escola por terem usado saia para ir à aula (haveria uma festa junina no intervalo). Moços e moças usaram saia como protesto na semana seguinte ao episódio ${ }^{28}$. E em setembro de 2014, alunos do colégio Dom Pedro II, no Rio de Janeiro, também vestiram saia como protesto ao fato de a instituição ter proibido uma aluna transgênero de ir à aula usando esta peça ${ }^{29}$.

Homens também têm usado a saia para protestar contra a proibição do uso de bermudas no trabalho, em dias de muito calor. Diferentemente das situações citadas antes, não é uma reivindicação pelo direito ao uso da peça feminina, e sim uma forma de questionar as normas vestimentares das organizações por meio da quebra de um código de vestuário muito mais rígido, que é aquele baseado na diferenciação de gênero. O código de gênero é naturalizado de tal forma que algumas organizações colocam a saia entre as peças-padrão de seus uniformes, mas sem especificar que só pode ser usada por mulheres. A mesma rigidez na aplicação do código que restringe o uso da bermuda faz com que não se possa proibir o uso da saia pelos empregados homens. Afinal, eles estão dentro do regulamento.

\footnotetext{
${ }^{26}$ Uma fonte para consulta desta prática pode ser a comunidade no Facebook intitulada "Homens de saia" (Perfil Homens de saia, n.d.). O perfil possui a seguinte descrição: "Página criada para informar, apoiar e defender o uso de Saias entre homens, independente de sua orientação sexual. Porque homens usam saias desde a antiguidade, porque roupa não tem gênero, porque preconceito não tem fundamento".

27 "Após ofensas, alunos da USP farão protesto com homens vestindo saia" (Moreno, 2013).

28 "Como protesto, alunos fazem 'saiaço' no colégio Bandeirantes" (Folha de São Paulo, 2013).

29 "Alunos do Colégio Pedro II fazem 'saiaço' em apoio a estudante transgênero proibida de usar saia na escola do Rio" (Iraheta, 2014).
} 
A saia foi usada como forma deste tipo de protesto pelos condutores de trem de Estocolmo, em junho de $2013^{30}$ (que, no fim das contas, experimentaram uma diminuição na liberdade de movimentos provocada pelo uso desta peça, algo com o que as mulheres estão habituadas a se defrontar em muitas situações). Outro episódio ocorreu no Brasil, em janeiro de 2014 - um dos mais quentes dos últimos tempos. O funcionário de um órgão público instalado em edifício no centro da capital carioca foi trabalhar de saia, já que homens são proibidos de entrar no local usando bermuda. O funcionário postou no Facebook uma foto sua usando a peça e, em poucas horas, o fato alcançou enorme repercussão ${ }^{31}$.

Ao falar sobre a experiência de vestir uma roupa aberta, muitos homens relatam algo que as mulheres vivenciam com bastante frequência: o prazer do contato da pele com o ar e com o tecido ocorre simultaneamente à insegurança de não ter nada "fechando" o meio das pernas. Uma insegurança que sempre lembra aos usuários da saia a violação física e simbólica que podem vir a sofrer por assumir o risco de vestir esta peça. Entendemos, portanto, que usar saia nestas condições tornou-se muito mais do que uma escolha pessoal baseada na moda, passando a ser uma decisão política.

\section{Considerações finais: a dimensão política da saia}

O que mostramos até agora são exemplos de uso da saia - como roupa e como elemento que constitui enunciados verbais e visuais de protesto - como símbolo e asserção do feminino. Estes exemplos foram precedidos de uma observação sobre o menor uso da saia pelas mulheres ocidentais nos dias de hoje, o que seria paradoxal se considerarmos que até relativamente pouco tempo a calça era proibida e a saia (e o vestido), compulsória. O menor uso da saia estaria relacionado justamente às situações de assédio e violência que os enunciados apresentados procuram denunciar e combater.

À observação sobre a rarefação da saia no guarda-roupa feminino poder-se-ia contrapor a argumentação de que a saia ainda é obrigatória ou frequente em determinados espaços ou situações: entre as fiéis de algumas religiões; no uniforme das comissárias de bordo; para as advogadas quando vão ao fórum ou ao tribunal. A saia aparece bastante, também, vestindo mulheres estadistas e que exercem cargos políticos.

No entanto, ao menos nos usos profissionais e religiosos, há um determinado tipo de saia aceito: aquela de formas verticalizadas, confeccionadas em tecidos mais pesados e cores neutras. Se a saia é figura de conteúdo do feminino, tais figuras plásticas compõem a categoria do masculino, de modo que a presença do feminino nestes espaços - o do trabalho e o governamental - é permitida desde que "vestido" com as marcas do masculino.

\footnotetext{
30 "BONNE CONDUITE - Privés de shorts, des conducteurs suédois viennent travailler en jupe" (Le Monde, 2013).

31 "Proibido de trabalhar de bermuda, homem vai de saia" (O Globo, 2014).
} 
Saias coloridas, amplas (horizontalizadas), de tecidos leves, aparecem frequentemente citadas como inadequadas, fantasiosas, pouco profissionais, sedutoras (Castro, 2002). Em resumo, a saia como figura de conteúdo do feminino confeccionada com elementos que são figuras de expressão do feminino (Baggio, 2014: 63) não são aceitas nestes ambientes ${ }^{32}$. Lembrando das saias usadas como símbolo dos protestos contra a violência feita às mulheres (figuras apresentadas nos itens 3 e 4), são modelos que, em sua maioria, possuem justamente esta dupla asserção do feminino.

De acordo com certos relatos, a saia é adequada quando a mulher está em espaços mais controlados ou, principalmente, quando está acompanhada: "E poi per l'uomo una donna che indossa la minigonna è un trofeo", diz a estilista Barbara Hulanicki (Lang, Schraml, Elster, 2011: 120). Subentende-se aí um controle da sexualidade feminina pelo homem e um fazerproteger esta mulher.

A mulher de saia sozinha na rua assume que sua sexualidade - já que a saia é vista como peça "sexual" - é independente do homem. A saia é disjunta do papel social da mulher sozinha por conta da permanência da rejeição à autonomia sexual da mulher. A mulher de saia na rua parece recusar o contrato da intimidação - que prescreve a necessidade de esconder sua sexualidade para não sofrer violência - e a mulher de saia "feminina" no trabalho recusa o contrato da masculinização como forma de valoração profissional.

Se o fazer discursivo que proporciona uma dimensão política é aquele que visa ou acarreta algum efeito de poder, entende-se que vestir saia, considerando as circunstâncias citadas até aqui, é um ato político. É um tipo de asserção do direito ao feminino, um feminino que não se restringe ao "ser mulher", mas a um modo "feminino" (em termos semânticos) de fazer ou compreender as coisas, com impacto profundo nos modos de ser e estar no mundo, como bem reflete Rose Marie Muraro:

"O que queremos dizer em última instância é que a entrada da mulher como sujeito maior na história começa a transformar a estrutura da força de trabalho dos países, na prática, bem como a administração do Estado e do mercado econômico. Além disto, implica, também, em uma nova visão das ciências, não só humanas como também exatas." (Muraro, 2001: 9).

Dando continuidade à lógica da definição apresentada no item 1 , se este efeito de poder é compreendido pela transformação das competências modais dos actantes (quem realiza ou sofre a ação em um programa narrativo) e de seus programas de ação, o que o uso da saia atualiza é um querer e um poder-desconstruir as normas de performance de gênero.

\footnotetext{
32 Em 2010, quando se candidatou à presidência do Brasil, Dilma Roussef não costumava usar saia. No entanto, suas blusas eram de cores vivas e com babados. Seus consultores de campanha teriam recomendado que deixasse os babados de lado, optando por formas mais sóbrias na vestimenta (Chaves, Soares, 2010). Os babados são elementos decorativos associados ao feminino, de acordo com a diferenciação de gênero em meados do século XIX e que pautam até hoje a classificação de masculino e feminino. Não se pode dizer que as saias recomendadas à Dilma expressam o feminino. Sua função, no vestuário de chefe de Estado, é de figurativizar a formalidade.
} 
Se a saia é usada em alguns discursos para figurativizar a mulher "puta", que merece sofrer violência (abstém-se aqui de deslindar todos os aspectos preconceituosos envolvidos na lógica deste xingamento) - e isto acontece quando a mulher não está cumprindo as regras de conduta impostas ao seu gênero -, é também reapropriada por outras práticas e discursos para questionar estas regras e a violência advinda de seu não-cumprimento.

O uso da saia fora destas normas mais ou menos explícitas expressa a adoção de um programa de ação diferente daquele esperado pelo sujeito que entende as normas como válidas. Há, portanto, uma quebra no contrato tácito que se estabelece entre as ordens do feminino e do masculino. É comum que o resultado da intersecção dos programas destes dois sujeitos resulte em violência física ou simbólica, conforme os diversos exemplos mostrados.

O que a presença da saia nos discursos de protesto busca também é mudar o programa de ação do poder público - conforme desejava a professora Sonia Bergerac, em La journée de la jupe -, para que tais atos de violência sejam punidos e, melhor ainda, nem cheguem a acontecer. Só desta forma assume-se que os direitos civis são efetivamente iguais para todos em termos de gênero, não importa se a performance da vida de um sujeito é tematizada pelo masculino ou pelo feminino.

\section{BIBLIOGRAFÍA}

- AlloCiné (2009): imagem do cartaz do filme "La Journée de la Jupe", [on line] Disponível em: http://www.allocine.fr/film/fichefilm_gen_cfilm=142311.html [03/11/2014].

- Perfil ArTIVISM (2013), imagem publicada em 12 de janeiro de 2013, sem informação de autoria, [on line] Disponível em: https:/www.facebook.com/photo.php?fbid=194687350675153\&set=a.133181980159024.38202.133 $176126826276 \&$ type $=1 \&$ theater [06/11/2014].

- Baggio, Adriana Tulio (2014): Mulheres de saia na publicidade: regimes de interação e de sentido na construção e valoração de papéis sociais femininos. Doutorado. Pontifícia Universidade Católica de São Paulo. Disponível http://www.sapientia.pucsp.br/tde_busca/arquivo.php?codArquivo=18005 [10/02/2016].

- Bard, Christine (2010): Ce que soulève la jupe. Paris: Éditions Autrement.

- Battaglia, Mattea; Gauchard, Yan e Laurente, Samuel (2014): "Ce que soulève la jupe: à Nantes, la polemique laisse la communauté éducative perplexe". Em: Le Monde, 15 de maio de 2014, [on line] Disponível em: http://www.lemonde.fr/societe/article/2014/05/15/ce-que-souleve-la-juge-anantes-la-polemique-laisse-la-communaute-educative-perplexe_4419338_3224.html [09/11/2014].

- Castro, Inês de (2002): A moda no trabalho. São Paulo: Editora Panda.

- Cia France (n.d.): imagem que ilustra a "Fiche pedagogique: La jupe", [on line] http://www.ciafrance.com/francais-et-vous/sous_le_platane/19-la-jupe-publicite-pour-\%C2\%AB-ni-putes-nisoumises-\%C2\%BB.html [01/11/2014].

- Chaves, Milene; Soares, Lucila (2010): "Programa de Aceleração do Carisma" [menu "Uniforme de Guerra" do infográfico]. Em: Veja, 31 outubro [online]. Disponível em: http://veja.abril.com.br/multimidia/infograficos/programa-de-aceleracao-do-carisma [17/02/2016]. 
- Colville-Andersen, Mikael (2011): "Short Skirts on Bicycles Celebration in New York City". Em: Cycle Chic, 11 de junho [online], Disponível em: http:// www.copenhagencyclechic.com/2011/06/short-skirts-on-bicycles-protest-in-new.html [15/06/2011].

- Crane, Diana (2006): A moda e seu papel social: classe, gênero e identidade das roupas [trad. Cristiana Coimbra]. São Paulo: Senac São Paulo, $2^{\mathrm{a}}$ Ed.

- Folha de São Paulo (2013) “Como protesto, alunos fazem 'saiaço' no colégio Bandeirantes”, 11 de junho de 2013, [on line] Disponível em: http://www1.folha.uol.com.br/fsp/cotidiano/113482como-protesto-alunos-fazem-saiaco-no-colegio-bandeirantes.shtml [07/11/2014]. *Acesso disponível apenas para assinantes do jornal.

- Greimas, Algirdas Julien; Courtés, Joseph (2008): Dicionário de Semiótica [trad. A. D. Lima et al.]. São Paulo: Contexto.

- Hollander, Anne (2003): O sexo e as roupas: a evolução do traje moderno [trad. Alexandre Tort; rev. Gilda Chataignier]. Rocco: Rio de Janeiro.

- Instituto de Pesquisas Econômicas Aplicadas (2014): "SIPS - Sistema de Indicadores de Percepção Social: Tolerância social à violência contra as mulheres", [online] Disponível em: http://www.ipea.gov.br/portal/images/stories/PDFs/SIPS/140327_sips_violencia_mulheres.pdf [07/11/2014].

- Iraheta, Diego (2014): “Alunos do Colégio Pedro II fazem 'saiaço' em apoio a estudante transgênero proibida de usar saia na escola do Rio". Em: Huffpost Brasil, 10 de setembro de 2014, [on line] Disponível em: http://www.brasilpost.com.br/2014/09/10/alunos-saia-rio_n_5800304.html [07/11/2014].

- Landowski, Eric (1992): A sociedade refletida: ensaios de sociossemiótica [trad. Eduardo Brandão]. São Paulo: Educ/Pontes.

- Lang, Bianca; Schraml, Tina; Elster, Lena (2011): La minigonna: la rivoluzione, gli stilisti, le icone [trad. Emanuela Damiani]. Vercelli, Itália: Edizioni White Star.

- Le Monde (2013): "BONNE CONDUITE - Privés de shorts, des conducteurs suédois viennent travailler en jupe", 9 de junho de 2013, [on line] Disponível em: http://bigbrowser.blog.lemonde.fr/2013/06/09/bonne-conduite-prives-de-shorts-des-conducteurssuedois-viennent-travailler-en-jupe/ [07/11/2014].

- Lemos, Nina; Tambellini, Karina (2008): “E aí, gostosa?”. Em: TPM, nº 74.

- Malini, Fábio; Antoun, Henrique (2013): A internet e a rua: ciberativismo e mobilização nas redes sociais. Porto Alegre: Sulina.

- Marçal, Carol (2015): “Qual o traje da nossa sociedade, afinal?". Em: Taco de Mulher, 2 de março [online]. Disponível em: http://www.tacodemulher.com.br/sem-censura/qual-o-traje-da-nossasociedade-afinal/ [15/02/2016].

- Melro, Ana (2012): “Femme de la rue', documentário sobre piropos gera polémica”. Em: Público, 19 de agosto [online]. Disponível em: http://p3.publico.pt/actualidade/4135/femme-de-larue-documentario-sobre-piropos-gera-polemica [04/11/2014].

- Ministère das Familles, de L'Enfance et des Droits des femmes (2012): Il y a 10 ans Sohane", [on line] Disponível em: http://femmes.gouv.fr/il-y-a-10-ans-sohane [03/11/2014].

- Moreno, Ana Carolina (2013): “Após ofensas, alunos da USP farão protesto com homens vestidos de saia". Em: G1, Globo.com, 13 de maio de 2013, [on line] Disponível em: http:/g1.globo.com/educacao/noticia/2013/05/apos-ofensas-alunos-da-usp-farao-protesto-comhomens-vestindo-saia.html [07/11/2014].

- Muraro, Rose Marie (2001): “Acerca do conceito de gênero". Em: Andréa Brandão Puppin e Rose Marie Muraro (Orgs.): Mulher, gênero e sociedade. Rio de Janeiro: Relume Dumará/Faperj, pp. 7-9.

- Ni putes ni soumise (2012): imagem da campanha "En jupe et pas soumise", [on line] Disponíveis em: www.npns.fr/boutique/badges/le-badge-en-jupe-et-pas-soumise-blanc [01/11/2014]. 
- O Globo (2014): "Proibido de trabalhar de bermuda, homem vai de saia", 4 de fevereiro de 2014, [on line] Disponível em: http://oglobo.globo.com/economia/emprego/proibido-de-trabalhar-debermuda-homem-vai-de-saia-11500233\#ixzz3IP4kPIYU [07/11/2014].

- Oliveira, Ana Claudia de (2008): "Nas interações corpo e moda, os discursos da aparência". Em: XIV Colóquio do Centro de Pesquisas Sociossemióticas - Caderno de Discussão, v. 1, p. 1-43 [CDROM].

- Perfil Ads of the world (2014): imagem publicada em junho de 2014, [on line] Disponível em: http://adsoftheworld.com/media/print/terre_des_femmes_a_womans_worth_2 [17/02/2016].

- Perfil Camila Neves (2014): imagem publicada em $1^{\circ}$ de abril de 2014, [on line] Disponível em:

- Perfil Em Piro (2013): imagem publicada em 18 de janeiro de 2013, sem autoria. [on line] Disponível em: https://www.facebook.com/photo.php?fbid=10100143642456494\&set=a.788664338514.2244009.33 $300569 \&$ type $=1 \&$ theater $[06 / 11 / 2014]$.

- Perfil Glbts - Guia Lgbts (2016): imagem publicada em 28 de janeiro de 2016, [on line] Disponível

em: https://www.facebook.com/guia.lgbts.glbts/photos/a.374317335972263.81690.372403632830300/97 2139449523379/?type $=3 \&$ theater $[13 / 02 / 2016]$.

Perfil Homens de saia (n.d.), [on line] Disponível em: https://www.facebook.com/HomensDeSaia [17/02/2016].

- Perfil Levante Popular da Juventude (2014): imagem publicada em 28 de março de 2014, [on line]

Disponível

em: https://www.facebook.com/photo.php?fbid=704666709598886\&set=a.321629677902593.80868.162 474053818157\&type=1\&theater [07/11/2014].

- Perfil Mulheres nos Quadrinhos (2014): imagem publicada em 18 de janeiro de 2014, [on line] Disponível

em: https://www.facebook.com/photo.php?fbid=663856440340962\&set=a.408435809216361.92810.408 425102550765\&type $=1 \&$ theater [06/11/2014].

- Perfil Não aguento quando (2014): imagem publicada em 28 de março de 2014, [on line] Disponível

em: https://www.facebook.com/NaoAguentoQuando/photos/a.210114225788193.56003.2074272827235 54/461264550673158/?type=1\&theater [07/11/2014].

- Perfil Poesia Ativista (2013): imagem publicada em 9 de maio de 2013. A autora da arte e do texto é Juliane KR, [on line] Disponível em: https://www.facebook.com/photo.php?fbid=555959524448670\&set=oa.480210882047951\&type=1 \&ref $=\mathrm{nf}[06 / 11 / 2014]$.

- Perfil Slutwalk France 2011 - Sexism is a social disease (2013): impressão de tela de postagem publicada em 11 de dezembro de 2013, [online] Disponível em: https://www.facebook.com/SLUTWALKFRANCE/posts/721686784515698:0 [06/11/2014].

- Perfil Tumblr Rosea Posey (2013): imagem publicada em 5 de janeiro de 2013, [on line] Disponível em: http://roseaposey.tumblr.com/post/39795409283/judgments [06/11/2014].

- Perfil Valesca Popozuda (2014): imagem publicada em 30 de março de 2014, [on line] Disponível

em: https://www.facebook.com/150627568320763/photos/a.197068783676641.65636.150627568320763 /709942219055959/?type=1\&theater [07/11/2014].

- Photography is not a crime (2014): fotografia publicada em 5 de março de 2014 em reportagem intitulada "Massachusetts Supreme Court Rules it's Legal to Record up Women's Skirts in Public"., [on line] Disponível em: https://photographyisnotacrime.com/2014/03/massachusetts-supreme-courtrules-upskirting-legal [05/11/2014]. 